\title{
Complications of bone lengthening
}

\author{
J. D. Aquerreta, F. Forriol, and J. Cañadell \\ Department of Orthopaedic Surgery, University Clinic, School of Medicine, University \\ of Navarra, Pamplona, Spain
}

\section{SUMMARY}

Bone lengthening is a surgical method which requires meticulous technique, continuous attention, and satisfactory cooperation on the part of the patient. The absence of common criteria makes it difficult both to classify the complications which arise, and to compare them with, those of other authors. We report the complications in a group of 61 patients who were studied prospectively. Disorders of the lengthening callus accounted for $45 \%$ of oil complications, and a further $33 \%$ arose in the joints. The remainder occurred in the bone, the apparatus and the soft tissues, of which the most common were stiffness of the joints, axial deviations and loosening of the pins, while articular subluxation, fractures with angulation and delayed consolidation occurred less frequently. In our study, the overall number of complications per lengthening process was 2.1. In bilateral lengthening, the rate was 1 per segment, while in unilateral cases the mean was 2.7. Problems which we defined as severe, requiring that the lengthening had to be halted, occurred in $1.8 \%$ of the total complications. The aetiology of the length discrepancy has an important role in the complications which occur in each segment. Over twice as many problems occur in asymmetrical lengthening procedures as in patients where lengthening is symmetrical.

\section{RÉSUMÉ}

L'allongement osseux est une intervention chirurgicale qui demande une technique méticuleuse, une surveillance médicale continue et une coopération satisfaisante du patient. En l'absence de critères communs il est difficile de classer les complications et de comparer avec les résultats d'autres auteurs. Si l'on analyse les complications selon leur localisation on, constate que les problèmes concernant le cal représentent $45 \%$ du total et ceux des articulations $33 \%$, soit un total d'environ $75 \%$ pour ces deux catégories. Les $25 \%$ restants se situent au niveau de l'os lui-même, du fixateur et des parties molles. Les incidents les plus fréquents sont les raideurs articulaires, les déviations axiales et l'ostéolyse autour des fiches, tandis que les subluxations, les fractures avec angulation et retard de consolidation s'observent moins souvent. Dans notre étude le total des complications est de 2.1 par allongement. Dans les allongements symétriques il est de 1 par segment, alors que dans les allongements asymétriques il s'élève è $2.7 \%$. Les problèmes que nous considérons comme graves, c'est à dire ceux qui compromettent le processus d'allongement représentent $1.8 \%$ du total des complications. L'étiologie joue un rôle important dans les complications qui surviennent au niveau de chaque segment. Les complications des allongements asymétriques sont deux fois plus fréquentes que celles des allongements symétriques. 


\section{INTRODUCTION}

The complications of bone lengthening are well described in the literature, but it is not easy to compare the results of different studies as they vary from $3 \%$ to $200 \%$ according to the criteria applied, the technique used, the composition of the study groups, the aetiology and the amount of lengthening. There is also great variation in the concept of what constitutes a complication; a small problem may sometimes be easy to solve, whereas on other occasions it leads to delay in or suspension of the lengthening process.

\section{MATERIALS AND METHODS}

The total of 61 patients surveyed in our prospective study [3] fall into two groups according to whether their treatment was unilateral (asymmetrical) or bilateral (symmetrical). This gives a total of 93 lengthening procedures and 142 lengthened segments. Thirty four patients presented with symmetrical short stature, and lengthening was carried out bilaterally with 49 procedures. Twenty seven patients were asymmetrical and unilateral lengthening was performed with 44 procedures (Table 1).

The data was obtained from the examination of every patient at each visit, and from the conventional radiographic and teleradiographic images used in assessment and followup of the lengthening procedures.

Lengthening was performed according to two basic techniques. In 130 segments progressive bone distraction followed percutaneous osteotomy in the metaphyseal or metaphyseo-diaphyseal area, and in 12 segments by means of physeal distraction. A unilateral external fixator, either a Wagner or a MONO-tube, was always used.

The beginning of distraction was delayed in all the osteotomies for a week and the lengthening rate in osteotomies and physeal distraction was set at $1 \mathrm{~mm}$ per day, performed either once a day or in two or four fractions.

In tibial lengthening a resection of $2-3 \mathrm{~cm}$ of the middle portion of the fibular diaphysis was performed, the most distal pin of the external fixator always being positioned to cross the tibia and fibula in order to prevent the fibula from moving proximally.

We divided the complications according to two criteria, namely the site, such as the joints, the callus, bone, soft tissues or the lengthening devices, and their importance. They were grouped into four categories according to their significance and their incidence during the lengthening process (Table 2).

\section{RESULTS}

Complications of type 1,2 and 3 were more frequent than those of type 4. Problems defined as severe, type 4 , meant that the process had to be halted, leaving sequelae; this occurred in 4 cases, amounting to $2 \%$ of the total complications. Type 3 complications were more frequent in both groups. In asymmetrical patients they accounted for $45 \%$ of the total complications (Table 3). 
Analysis of the incidents according to location, showed that disorders of the lengthening callus accounted for $45 \%$ of all the complications studied (Figs. 1 and 2) and a further $34 \%$ arose in the joints. The remaining $21 \%$ consisted of problems in the bones, the apparatus or the soft tissues. The commonest complications were stiffness of the joints, axial deviation and loosening of the pins (Fig. 3), while articular subluxation, fractures with angulation (Figs. 4 and 5) and delayed consolidation occurred less frequently. As regards malalignment, valgus angulation of the tibia was more frequent than varus deviation of the femur.

The overall percentage of complications per lengthening process was $214 \%$. In symmetrical lengthening, the rate was $104 \%$ per segment, while in cases of asymmetry the mean was $268 \%$ (Table 5).

A high relationship existed between the com-plication rate, the aetiology and the bone lengthened. In patients undergoing symmetrical lengthening, the overall numbers of complications occurring in the femur and the tibia were similar, whereas far fewer arose in the humerus (Table 5). In the symmetrical group, we found that dysplastic patients had fewer complications in the femur than in the tibia, while in non-dysplastic patients the contrary was true. The tibial complications in both groups were similar. In cases of asymmetry, the complications in the femur and tibia were comparable whether the condition was congenital or acquired. Twice the number of complications follow asymmetrical rather than symmetrical lengthenings. The high incidence of complications found in lengthened bones of the hand and foot should be borne in mind (Table 5).

No significant relationships were found between different age groups, the sexes and the lengthening techniques used, or between the extent of elongation and the complications. However, the aetiology was found to have a significant bearing on the rate of complications.

\section{DISCUSSION}

The overall percentage of complications in the literature is high, exceeding $100 \%$ [ 4,5 , $6,7,14,15,16,18,19,20,23]$. Although the muscles and fasciae grow as the limb is extended, problems can arise when the muscle growth rate is slower than the lengthening of the bone. In most reports, disorders of the joints are the most common serious complication [7, 22, 24]. However for Paley [21] muscle problems predominated, while Guarniero et al. [14] rank superficial and deep infections of the pins among the greatest problems. High complication rates are found in patients with congenital short femurs [13] when compared to dysplastic patients of low stature, probably because the latter experience fewer difficulties in moving their joints; their muscles and vessels are longer than their bones $[9,10]$ and the condition of their tissues prior to lengthening is generally better [7].

The risk of joint stiffness increases dramatically when the bone is lengthened by more than 15\% [8], and Franke et al. [9] maintain that lengthening should not exceed $25-40 \%$ of the original bone length, except in cases of achondroplasia. It is important with physeal distraction to be especially careful to avoid damaging the growth and articular 
cartilage when inserting pins into the epiphysis. Other complications may also be secondary to the location of the pins in the epiphysis, such as inflammatory arthritis.

The muscle imbalance produced during the lengthening process can cause subluxation of the knee joint. The knee is the joint which suffers most from lengthening, and a loss of extension is commonly produced. As a preventive measure we ad-vise that the knee should be kept in permanent extension during lengthening. Problems in the hip joint are uncommon and tend to be associated with acetabular dysplasia. The ankle presents a high incidence of complications such as equinus deformity.

The degree and type of axial deviation depends on the bone being lengthened, the technique used, and the position of the osteotomy. There is a tendency for the segment being lengthened to deviate gradually as a result of the imbalance of the muscular forces acting on different parts of the bone. Osteotomies of the proximal femur and distal tibia tend to varus deviation and anterior bowing, whereas osteotomies sited in the distal femur and proximal tibia are followed by valgus deviation and anterior bowing.

Pin problems probably start from the skin and spread to deeper soft tissues and the bone. The prevention of these complications is the responsibility of the patient himself, who must observe a high standard of hygiene as far as the skin is concerned.

The timing of removal of the external fixator is of great importance in the prevention of possible complications. Vade et al. [23], and our own study, provide evidence that there is a high risk of fracture and subsequent deformity when the fixator is removed before a complete cortex on both sides of the lengthened callus is evident radiologically.

The reported incidence of nerve lesions ranges from $5 \%$ to $30 \%$, but this estimate may be misleading as subclinical alterations seem to be even more common [11]. We found that the EMG pattern was normal in $70 \%$ of cases [2]. Where complications of this type are suspected, distraction should be slowed down or even suspended, although this may be followed by premature consolidation. Similarly, vascular lesions may arise through surgical error, or as a result of distraction. They are very rare when monolateral fixators are used, but seem to be a constant feature with circular fixators which rely on transfixing wires [12].

Lengthening is a laborious technique which requires great care, and should only be undertaken at the patient's request. Difficult social and family situations can arise, often because of the length of time necessary for this procedure. Bone lengthening can occasionally cause psychological problems, requiring psychotherapy $[1,17]$.

The prevention and early detection of complications depend on the use of appropriate surgical techniques, effective clinical management, and painstaking radiological followup. Premature removal of the fixator should be avoided whenever possible.

\section{REFERENCES}

1. Aguirre M (1990) Aspectos psicológicos de las personas de baja estatura. In: J de Pablos, J Cañadell (eds) Elongación ósea. Estado actual y controversias. Servicio de Publicaciones Universidad de Navarra, Pamplona 
2. Cañadell J, Pastor MA, Casado M, Artieda J, Forriol F (1993) Quantitative EMG study in bone lengthening. 1st European Congress of Orthopaedics, Paris, 273

3. Cañadell J, Aquerreta D, Forriol F (1993) Prospective study of bone lengthening. J Paediatr Orthop Part B 2: 1-7

4. Coleman SS, Scott SM (1991) The present attitude toward the biology and technology of limb lengthening. Clin Orthop 264: 76-83

5. Conejero JA, Florez MT, Salcedo J, Amaya J (1991) Elongaciones óseas en malformaciones congénitas de las extremidades inferiores. An Esp Pediatr 34: 293-298

6. Dutoit M, Rigault P, Padovani JP, Finidori G, Touzet P, Durand Y (1991) Le devenir des enfants opérés d'allongement pour hypoplasie congénitale des membres inférieurs. Rev Chir Orthop 76: 1-7

7. Faber FW, Keessen W, Van Roermund PM (1991) Complications of leg lengthening. 46 procedures in 28 patients. Acta Orthop Scand 62: 327-332

8. Fischer J, Dufek $\mathrm{P}$, Stachel $\mathrm{P}$ (1992) GliedmaBen-verlängerung durch Epiphysen- und Kallusdistraktion mit dem Wiesbadener Ringfixateur. Orthopä de 21: 210-214

9. Franke J, Hein G, Simon M, Hauch S (1990) Comparison of distraction epiphyseolysis and partial metaphyseal corticotomy in leg lengthening. Int Orthop 14: 405-413

10. Franke J, Simon M, Hein G (1992) Ilizarov-Techniken zur Beinverlängerung. Orthopáde 21: 197-209

11. Galardi G, Comi G, Lozza L, Marchettini P (1990) Peripheral nerve damage during limb lengthening. J Bone Joint Surg 72: 121-124

12. García E, Fernández N, Olsen B, Ruiz M (1992) El método de Ilizarov en cirugía de alargamiento. Rev Ortop Traum 36-IB: 438-453

13. Grill F (1989) Correction of complicated extremety de-formities by external fixation. Clin Orthop 241: 166-176

14. Guaniero R, Montenegro NB, Guanieri MV, Rossi J (1993) Comparative study of Ilizarov, Wagner, and Anderson methods for limb lengthening (100 lengthenings in 98 patients). J Paediatr Orthop Part B 2: 28-34

15. Herzog R, Hefti F (1992) Problematik und Komplikationen der Beinverlängerungen mit dem Wagner-Apparat. Orthopáde 21: 221-229

16. Hood RW, Riseborough EJ (1981) Lengthening of the lower extremity by the Wagner method. J Bone Joint Surg 63: 1122-1131

17. Hrutkay JM, Eilert RE (1990) Operative lengthening of lower extremity and associated psychological aspects: the children's hospital experience. J Paediatr Orthop 10: 373-377

18. Korzinek K, Tepic S, Perren SM (1990) Limb lengthening and threedimensional deformity corrections. A retrospective clinical study. Arch Orthop Trauma Surg 109: 334-340

19. Monticelli G, Spinelli R, Iorio L, Forte R (1990) Complications in elongations using circular fixators. In: J de Pablos, J Cañadell (eds) Bone lengthening. Current trends and controversies. Servicio Publicaciones Universidad de Navarra, Pamplona

20. Mosca V, Moseley CF (1986) Complications of Wagner leg lengthening and their avoidance. Orthop Trans 10: 462-468

21. Paley D (1990) Problems, obstacles and complications of limb lengthening by the Ilizarov technique. Clin Orthop 250: 81-104 
22. Pfeil J, Niethard FU (1990) Unterschenkelverlängerung mit dem IlisarovSystem. Orthopäde 19: 263-272

23. Vade A, Eissenstat R (1990) Radiographic features of bone lengthening procedures. Radiology 174: 531-537

24. Wagner H (1978) Operative lengthening of the femur. Clin Orthop 136: 125-142 


\begin{tabular}{|l|l|}
\hline \multicolumn{2}{|l|}{ Table 1. General data of the study } \\
\hline Number of patients & 61 \\
\hline Sex & \\
\hline Males & 38 \\
\hline Females & 23 \\
\hline Lengthening procedures & 93 \\
\hline Lengthened segments & 142 \\
\hline Aetiology & \\
\hline Symmetrical short stature & 34 patients \\
\hline Asymmetrical shortening & 27 patients \\
\hline Procedures & \\
\hline Bilateral & 49 \\
\hline Unilateral & 44 \\
\hline Technique & \\
\hline Percutaneous osteotomy & 130 segments \\
\hline Physeal distraction & 12 segments \\
\hline Means of lengthening & \\
\hline Total & $8,4 \mathrm{~cm}$ \\
\hline Symmetrical & $11,2 \mathrm{~cm}$ \\
\hline Asymmetrical & $5,5 \mathrm{~cm}$ \\
\hline
\end{tabular}

\begin{tabular}{|l|l|}
\hline \multicolumn{2}{|c|}{ Table 2. Significance of the complications in bone lengthening } \\
\hline Type 1 & $\begin{array}{l}\text { Complications for which no cessation of the lengthening process is } \\
\text { required and which can be managed with no affect on the final result }\end{array}$ \\
\hline Type 2 & $\begin{array}{l}\text { Complications which require temporary cessation of the lengthening } \\
\text { process or which are manageable by means of associated surgery }\end{array}$ \\
\hline Type 3 & $\begin{array}{l}\text { Complications occurring during or following lengthening and which } \\
\text { interfere with the final result either aesthetically or functionally }\end{array}$ \\
\hline Type 4 & $\begin{array}{l}\text { Complications which require permanent cessation of the lengthening } \\
\text { process and possible removal of the fixator }\end{array}$ \\
\hline
\end{tabular}

Table 3. Significance of complications with regard to aetiology and total length increase (141 procedures)

\begin{tabular}{|l|c|c|c|c|c|c|}
\hline & \multicolumn{2}{|c|}{ Total } & \multicolumn{2}{c|}{ Symmetrical } & \multicolumn{2}{c|}{ Asymmetrical } \\
\hline Lengthening $(\mathrm{cm})$ & \multicolumn{2}{|c|}{11.2} & \multicolumn{2}{c|}{11.8} & \multicolumn{2}{c|}{10.2} \\
\hline & Total & $\%$ & Total & $\%$ & Total & $\%$ \\
\hline Type 1 & 60 & 27.3 & 30 & 29.4 & 30 & 25.4 \\
\hline Type 2 & 65 & 29.5 & 32 & 31.4 & 33 & 28.0 \\
\hline Type 3 & 91 & 41.4 & 38 & 37.3 & 53 & 44.9 \\
\hline Type 4 & 4 & 1.8 & 2 & 1.9 & 2 & 1.7 \\
\hline Total & 220 & 100.0 & 102 & 100.0 & 118 & 100.0 \\
\hline
\end{tabular}




\begin{tabular}{|c|c|c|c|c|}
\hline & $\begin{array}{l}\text { 4. Classification of location } \\
\text { verity of com }\end{array}$ & $\begin{array}{l}\text { S relati } \\
\text { on }\end{array}$ & & he se- \\
\hline & cation & Severity & No. & $\%$ \\
\hline 1. & Articular complications & & & \\
\hline & articular stiffness & Type 1 & 40 & 18.2 \\
\hline & articular subluxation & Type 2 & 28 & 12.7 \\
\hline & articular luxation & Type 2 & 2 & 0.9 \\
\hline & early degeneration & Type 3 & 2 & 0.9 \\
\hline & inflammatory arthritis & Type 4 & 2 & 0.9 \\
\hline & & Total & 74 & 33.6 \\
\hline 2. & Lengthening callus disorders & & & \\
\hline & delayed consolidation & Type 2 & 12 & 5.4 \\
\hline & early consolidation & Type 2 & 1 & 0.5 \\
\hline & axial deviation & Type 3 & 45 & 20.5 \\
\hline & fractures with collapse & Type 3 & 4 & 1.8 \\
\hline & fractures with angulation & Type 3 & 24 & 10.8 \\
\hline & collapse without fracture & Type 3 & 5 & 2.3 \\
\hline & pseudoarthrosis & Type 3 & 3 & 1.4 \\
\hline & asymmetries & Type 3 & 5 & 2.3 \\
\hline & & Total & 99 & 45.0 \\
\hline 3. & Bone disorders & & & \\
\hline & fractures & Type 2 & 6 & 2.8 \\
\hline & fibula disorders & Type 2 & 10 & 4.5 \\
\hline & early physeal closure & Type 3 & 3 & 1.4 \\
\hline & & Total & 19 & 8.7 \\
\hline 4. & External fixator disorders & & & \\
\hline & pin loosening & Type 1 & 17 & 7.6 \\
\hline & pin bending & Type 2 & 3 & 1.4 \\
\hline & & Total & 20 & 9.0 \\
\hline 5. & Soft tissue disorders & & & \\
\hline & mild neurovascular & Type 2 & 4 & 1.8 \\
\hline & severe neurovascular & Type 4 & 2 & 0.9 \\
\hline & mild infections & Type 2 & 1 & 0.5 \\
\hline & severe infections & Type 4 & 1 & 0.5 \\
\hline & & Total & 8 & 3.7 \\
\hline
\end{tabular}


Table 5. Elongated segment complications: percentage according to aetiology

\begin{tabular}{|c|c|c|c|c|c|c|}
\hline Segment & \multicolumn{3}{|c|}{ Symmetrical } & \multicolumn{3}{c|}{ Asymmetrical } \\
\hline & Total \% & $\begin{array}{c}\text { Dysplastic } \\
\%\end{array}$ & $\begin{array}{c}\text { Non- } \\
\text { dysplastic } \\
\%\end{array}$ & Total \% & $\begin{array}{c}\text { Congenital } \\
\%\end{array}$ & $\begin{array}{c}\text { Non- } \\
\text { congenital } \\
\%\end{array}$ \\
\hline Femur & 104.5 & 75.0 & 183.3 & 260.7 & 265.0 & 250.0 \\
\hline Tibia & 108.3 & 108.3 & 108.3 & 266.6 & 275.0 & 250.0 \\
\hline Humerus & 66.6 & 66.6 & - & - & - & - \\
\hline Metatarsals and metacarpals & - & - & - & 325.0 & 300.0 & 333.3 \\
\hline Total & $104 \%$ & $87.1 \%$ & $133.3 \%$ & $268.2 \%$ & $268.9 \%$ & $266.6 \%$ \\
\hline
\end{tabular}




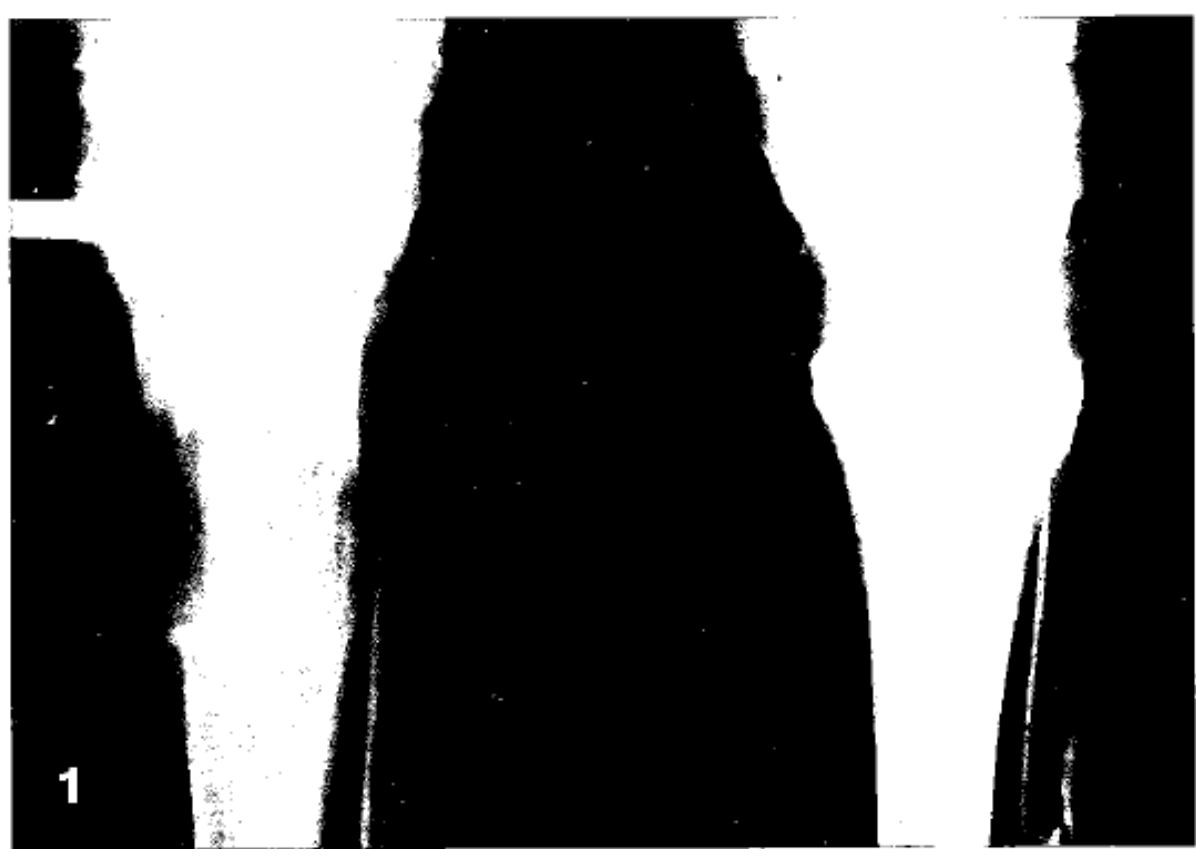

Figure 1. Tibial lengthening. Collapse of callus after removal of fixator

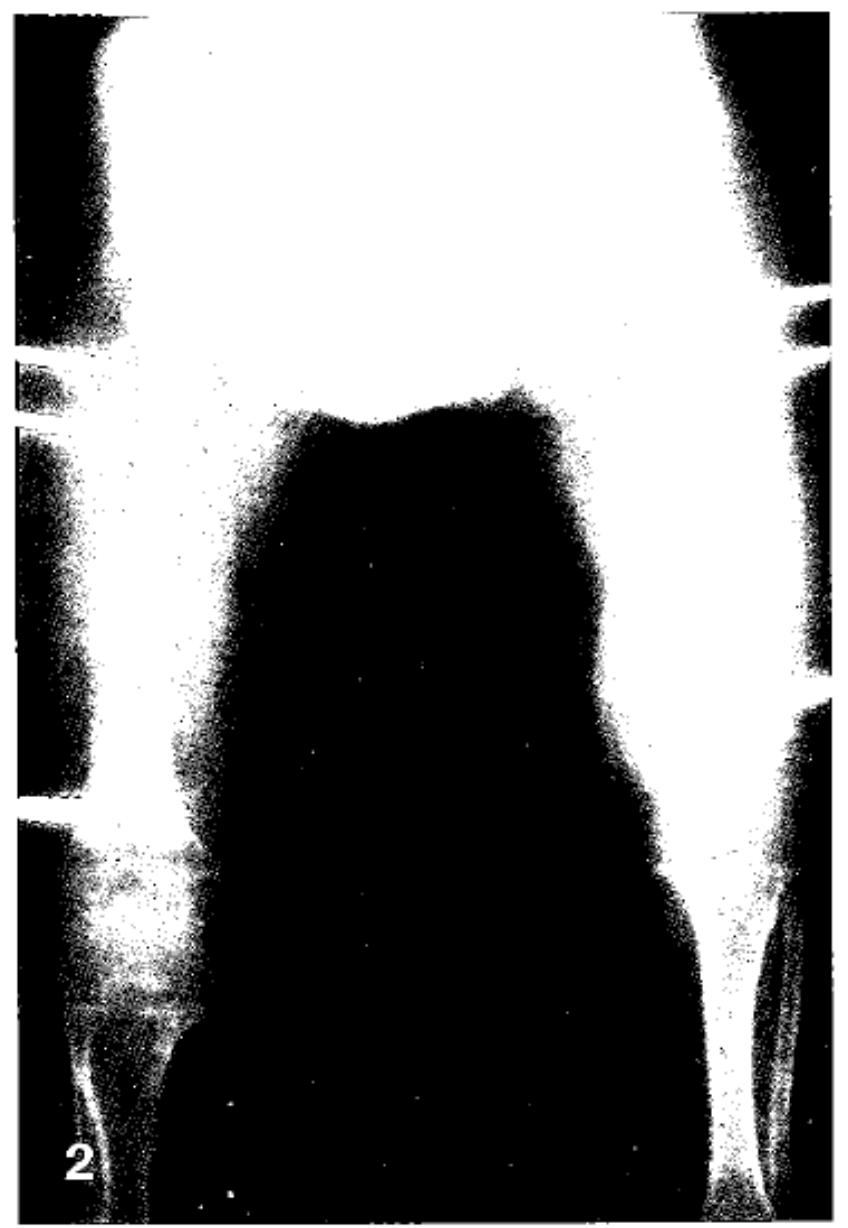

Figure 2. Premature consolidation in lengthened callus in the left femur 


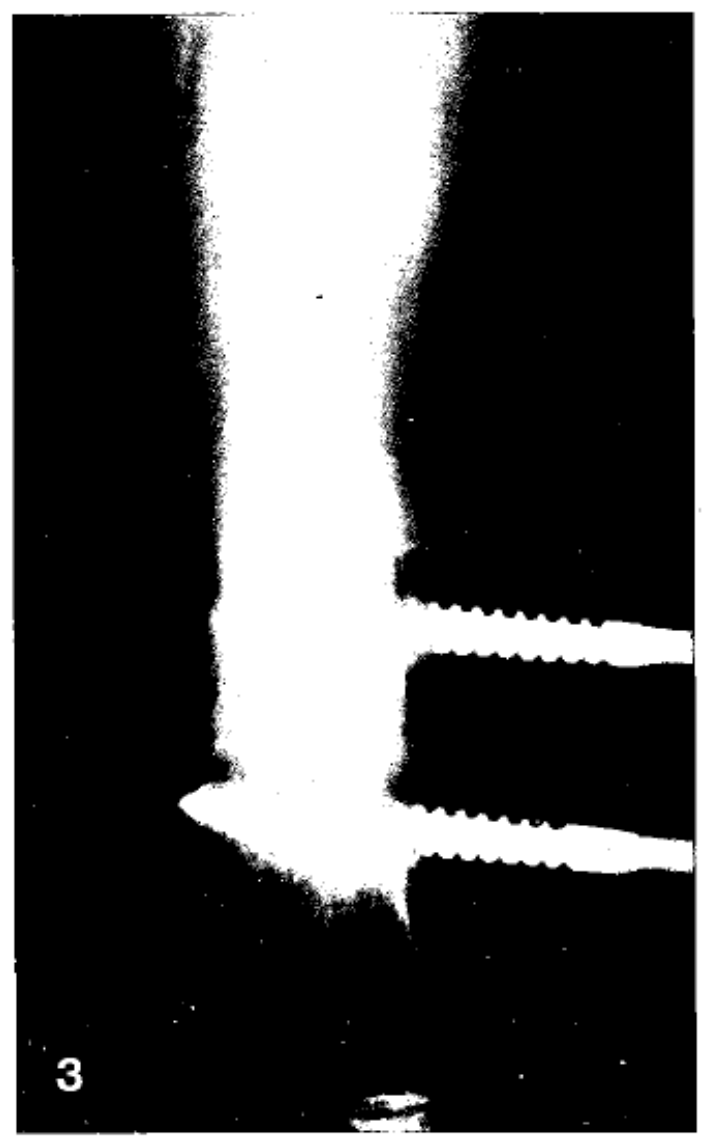

Figure 3. Osteolysis around the pins in femoral lengthening

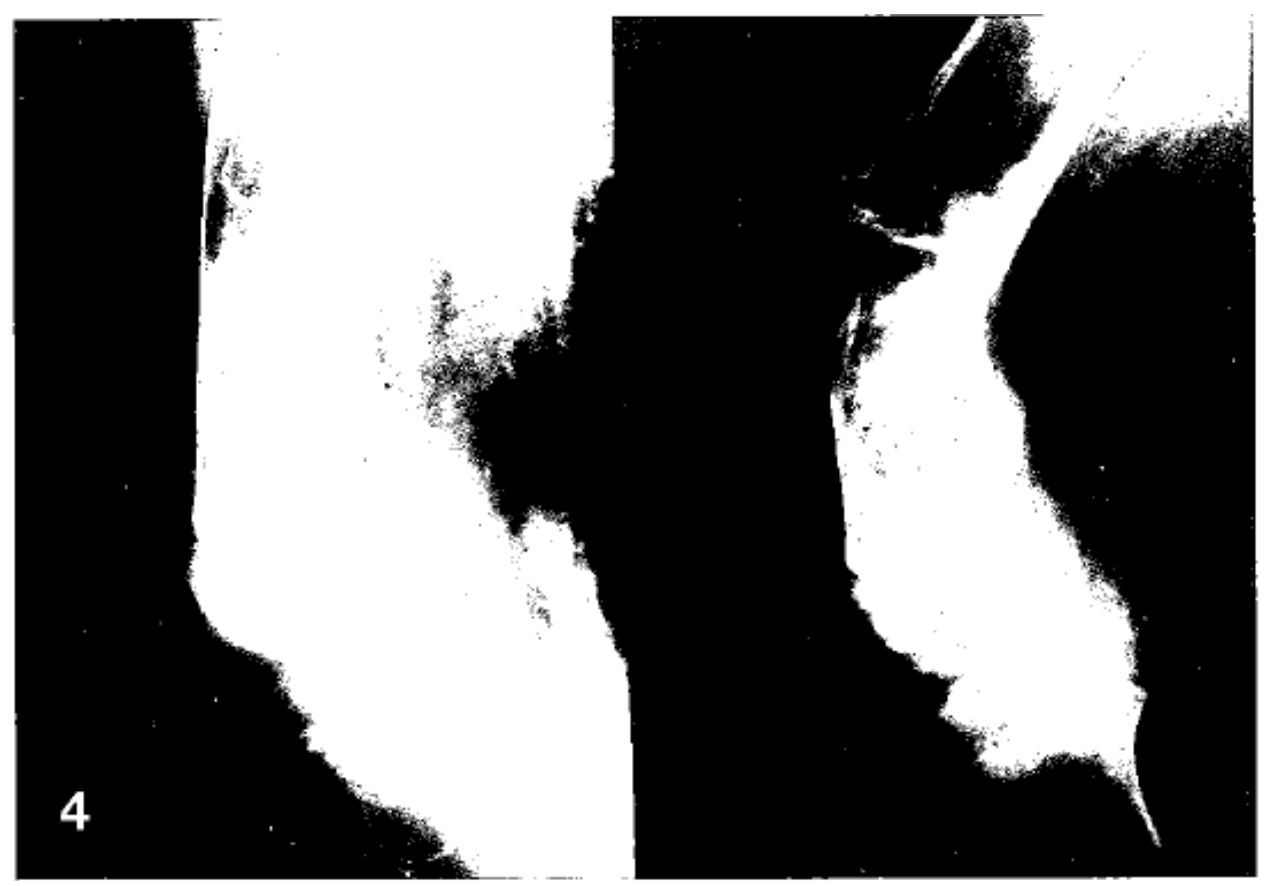

Figure 4. Angulation of lengthened callus after removal of plaster cast 


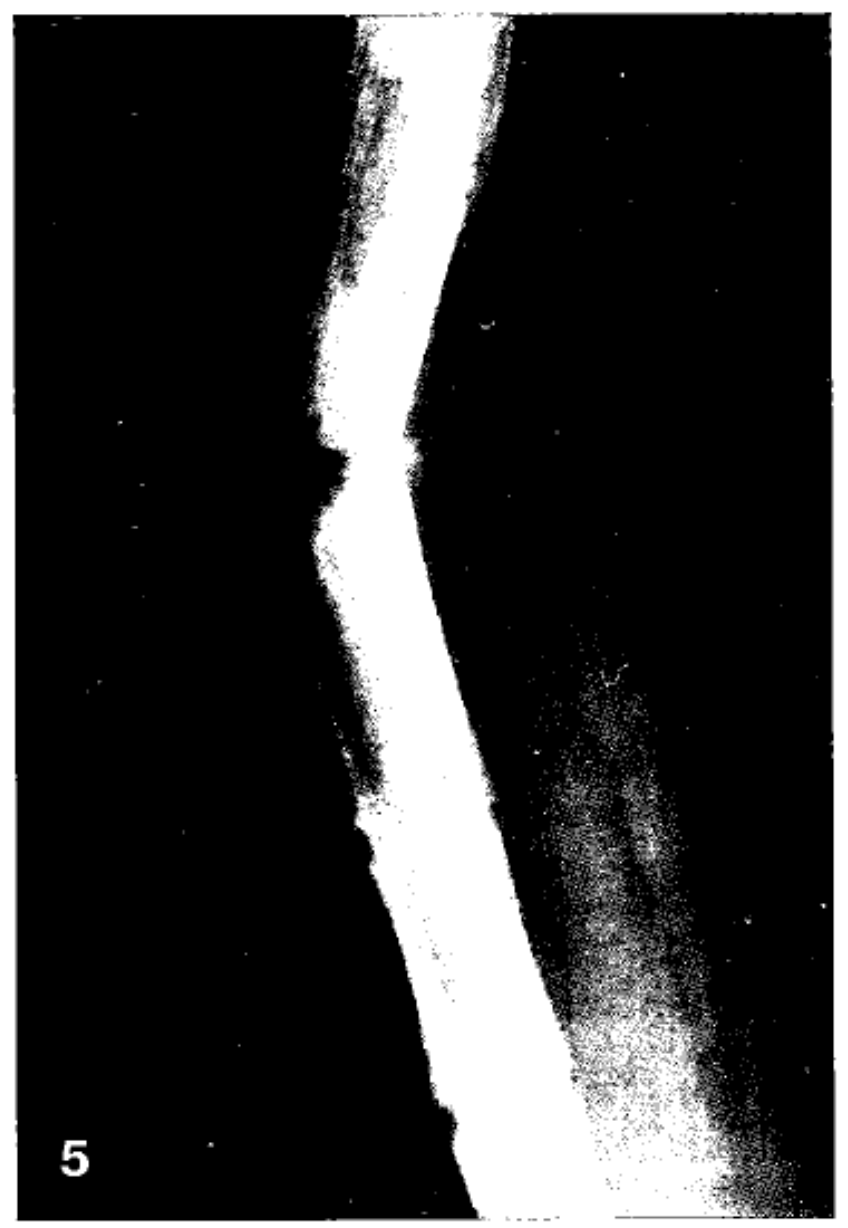

Figure 5. Fracture of callus caused by trauma after completion of lengthening 